\title{
NOVEL NON-AQUEOUS ELECTROLYTES BASED ON COORDINATION
} BORON COMPOUNDS

\section{A. Diamant}

Vernadsky Institute of General \& Inorganic Chemistry NAS Ukraine, 32/34, Akad. Palladin Avenue, 03680 Kyiv, Ukraine

Email:carbon.h.4@gmail.com

There view provides a classification of electrolytes for modern chemical power sources, supercapacitors, sodium and lithium-ion batteries depending on changes in the physicochemical properties of salts and the products of their interaction with the solvent. A comparative analysis of physicochemical properties of salts depending on the structure of the cation and anion, and the influence of these properties on the properties offinal solutions of electrolytes on the example of different classes of ionic liquids and chelatoborates of alkalimetals and ammonium was conducted. Emphasis is placed on the physicochemical properties of solutions of the most promising chelatoborate salts for use in lithium and sodium-ion batteries, supercapacitors, and electrolytic capacitors, and it is shown that bis(oxalate)borates and bis(salicylato)borates occupy borates in terms of electrical conductivity, solubility, and potential range of electrochemical stability.

Key words: salt, cation, anion, solvent, ionic liquids, coordination compounds of boron, electrolytes for electrochemical energy storages.

INTRODUCTION. The development of modern chemical power sources, such as supercapacitors, sodium and lithiumion batteries, requires electrolyte systems based on non-aqueous solutions and ionic liquids (molten salts at room temperature). The research of electrolytes and the theory of their structure has been the subject of the scientists' attention during the last two centuries [1] due to the transport of substances to the redox reaction site and participation in the formation of a double electrical layer at the electrode-electrolyte boundary. An important class of salt compounds whose solutions have been used as electrolytes is bis(chelato)borates. Such salts as bis(oxalato)borates and bis(salicylato)borates occupy the main place among all known bis(chelato)borates in terms of electrical conductivity, solubility, and the range of electrochemical stability potentials. Mixed salts with two different chelate ligands typically combine the best characteristics of the corresponding monochelate compounds, and the methods for their preparation and purification are much more numerous compared to monochelate compounds [2-5]. However, the transport functions of these salts depend on the structure and composition of electrolytes, forming 
their physical and chemical features [6]. To establish the factors that have the most impact on the properties and prospects for the use of such salts, it is necessary to consider and summarize the impact of different organic cations, boron content, anion interaction with protic and aprotic solvents, and changes in the properties of the electrolyte due to the ability for the coordination of the salt to solvents.

THE EFFECT OF SOLVENTS ON THE COMPOSITION AND STRUCTURE OF LIQUID ELECTROLYTES

The modern classification concepts of non-aqueous electrolytes based on the level of their dissociation (strong and weak) became obvious when a profound research of ion processes in non-aqueous solvents began (P. Valden, Ch. Kraus, P. Fuoss, N A. Izmailov) [1]. Indeed, it turns out that a lot of electrolytes being able to dissociate fully in water (hydrogen chloride, nitrogen and perchloric acid, and many other salts) are weak in nonaqueous solvents, where they act according to the low of mass action. It became clear that the strength of the electrolyte (the ability to dissociate into ions) is not its permanent property, but is also determined by the solvent nature. The more rational novel method divides electrolytes into real electrolytes (ionophores) and pseudo-electrolytes (ionogens). The ionophores are compounds existing already in the ion form while being in a condensate state. To put it in other words, they are inorganic salts $\left(\mathrm{NaCl}, \mathrm{K}_{2} \mathrm{SO}_{4}\right)$ as well as organic salts $\left(\mathrm{N}\left(\mathrm{C}_{2} \mathrm{H}_{5}\right) 4 \mathrm{Pic}\right)$. On the opposite, the ionogens form ions only while contacting with a solvent. The ionogens include, for example, vinegar acid, benzoic acid, hydrogen chloride, and others [1]. Thus, a solvent is an integral part of an electrolyte, and its chemical and physical properties influence greatly the further changes in its electrolyte system properties. Nowadays, there are several solvent classifications. First, the solvents are grouped according to their composition [3]:

Molecular fluids (molecular combinations which have covalent bonds only):

- ionic fluids (molten salts, ionic bonds only);

- atomic fluids (fusible metals, they have metallic bonds).

Second, based on their physical properties [3]:

- low-temperature boiling (under $100^{\circ} \mathrm{C}$ ):

- high-temperature boiling (over $150^{\circ} \mathrm{C}$ ):

- medium-temperature boiling (over $100^{\circ} \mathrm{C}$, but less than $150^{\circ} \mathrm{C}$ ).

Also, the solvents are classified as polar protic (aqueous) and non-polar aprotic (nonaqueous). Consequently, there are four different types: protic polar and protic weak polar, aprotic polar, and aprotic non-polar solvents [7, 8].

Considerable attention has been devoted during the last decades to the studies of ionic fluids. They are divided into protic, aprotic and zwitterionic fluids (where anion and cation are in the same molecule) [9]. The aprotic ionic fluids are the most promising for the use in chemical power sources thanks to low vapor pressure over the solvent $[10,11,12]$, broad fluid state region, a wide range of electrochemical stability working potentials, low melting point, moderate conductivity, $\left(0.1-18 \mathrm{mS} / \mathrm{cm}^{2}\right)$ [13], hydrophobic nature and resistance to inflammation $[9,14]$. The flaws of ionic fluids include high viscosity [13] and surface tension, which lead to low cohesion with the electrodes. Thanks to their remarkable features, the ionic fluids are used more and more widely. For example, they are used in nuclear power as liquid nuclear fuel 
carriers [11], as initiators in polymerization reactions [12], as compounds of electrolytes for supercapacitors $[9,11-16]$, and lithium-ion batteries [13]. According to this classification, the bis(chelato)borates have many features of ionic fluids. But till today, the impact of cations and anions of such salts to change the properties of electrolytes hasn't good background.

ORGANIC CATION IMPACT

There exist two tendencies in the theoretical views of cation's role in electrolyte: (1) the main transport function as a current carrier $[1,6],(2)$ agent of salt-solvent systems [15]. In the transport of current as charge carrier, inorganic cations such as lithium, potassium, and sodium cations usually take part [15]. Organic cations, as part of ionic liquids, have more complex functions due to bigger sizes and low mobility. Such properties change the mechanism of charge transfer, which strongly depends on the solvent nature $[16,17]$.

The most renowned agents of this class of compounds are different salts of replaced imidazolium and pyrrolidinecations and the salts of tetraalkylammoniumcation [13]. The alternative studies are targeting the other cations: Trialkylsulphonium, tetraalkylphosphonium, alkylpyridinium, $\mathrm{N}$-alkyltiosolinium, N, N-dialkyltriasolinium, N, N-dialkyloxasolinium and N, N-dialkylpyrazolinium (Figure 1).<smiles>[R][n+]1ccccc1</smiles>

alkylpyrydinium

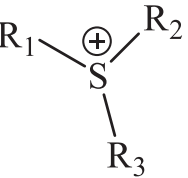

trialkylsulphone<smiles>[R][N+]1([R])CCCCC1</smiles>

$\mathrm{N}, \mathrm{N}$-dialkylpiperidinium<smiles></smiles>

$\mathrm{N}$-alkylimidazolinium

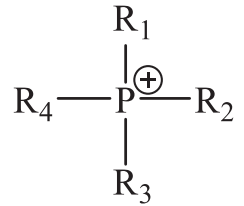

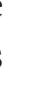


It was found that for such solvents as DMSO, propylene carbonate, and other aprotic dipolar solvents in the case of lithium salts and organic cations, the electrolyte has a specific structure, which does not depend on dissociation level. [18-22]. Ions in solution form supramolecular structures - ion pairs separated by a solvent and contact ion pairs, which exist in a certain equilibrium depending on the concentration [18-22]. If the transport properties of alkali metal cations depend on their solvation energy with solvents, then in the case of an organic cation, since it is practically not solvated, it affects the properties of the solution more due to size, symmetry, and charge distribution.

\section{ORGANIC ANION IMPACT}

In the salts of novel electrolytes, the most well-known anions are $\mathrm{ClO}_{4}, \mathrm{PF}_{6}^{-}$and $\mathrm{BF}_{4}^{-}$or organic ions: trifluoroalkyl sulfates, trifluoromethanesulfonimide and trifluoromethanesulfonamethanides, and more recently bis(chelato)borate and tris (chelated complex) phosphates [23-30]. Decreasing the symmetry of the anion, increasing its size, introducing functional groups, and changing the ratio of the anion radius to the cation radius directly affect the melting temperature and solubility of the salt as in the case of the cation. Therefore, the structure of the salt anion, as well as the interaction with the solvent, affect the structure of the solution and its transport properties no less than the structure of the cation [31-33].

However, charge transport can occur due to a cation and an anion. This can be determined experimentally by measuring the transfer numbers and comparing them. According to the classical theories of electrolytic dissoci- ation, it is believed that inorganic anions are hardly solvated, while large organic anions do not obey classical laws and can form together with solvents structures similar to polymers and solvate complexes. For ionic liquids in the formation of polymer structures or in the formation of zwitterion, the characteristic Grotthuss (relay) mechanism of charge transport with the formation of free volume is realized [34-35]. The presence of apseudopolymer structure in the salt-solvent system changes the transport function of electrolytes due to a change in dielectric properties and conductivity [36-40].

Therefore, to account for the impact of the anion on the properties of the electrolyte, it is necessary to take into account the size and steric properties of the anion, the nature of the solvent, and the peculiarities of its interaction with the anion. In this case, the most interesting are the complex compounds of boron with bidentate ligands.

\section{COORDINATION COMPOUNDS OF BORON}

The literature confirms that despite the possibility of the boron coordination number of 3 or 4, bidentate ligands add to the coordination diversity and even to the formation of coordination polymers (table 1). Thus, the boron compounds have predisposition to polymerization while the coordination number of 4 is available. This must influence the electrochemical and physical properties of the electrolyte systems based on them. Therefore, the synthesis method has an important role to play. The solvents or neutral molecules also can coordinate in the outer sphere, e.g. $\mathrm{H}\left[\mathrm{B}\left(\mathrm{OC}_{5} \mathrm{H}_{11}\right)_{4}\right]^{\star} 4 \mathrm{C}_{5} \mathrm{H}_{5} \mathrm{~N}[41]$. 


\section{Table 1}

The composition and properties of the complex boron compounds

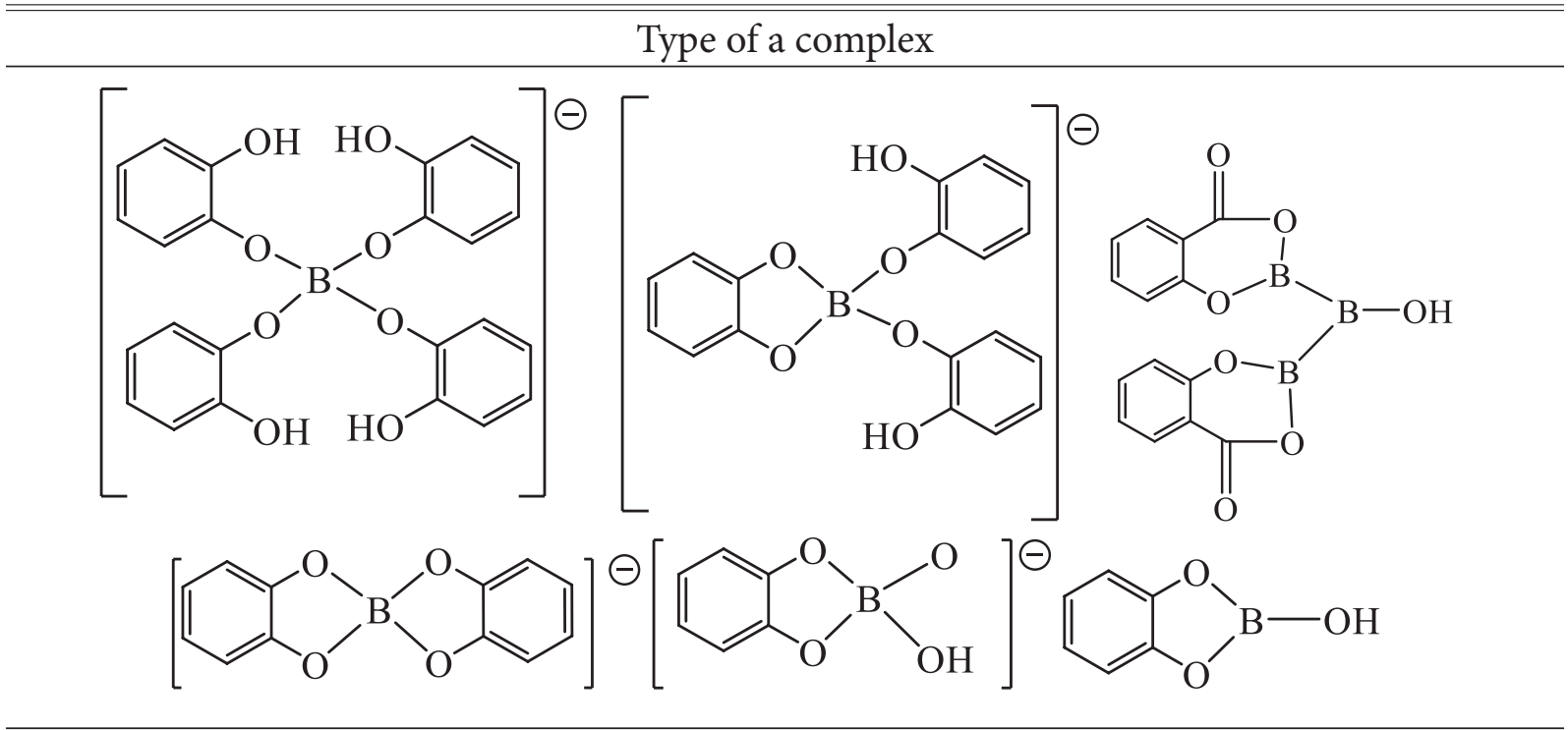

The ability to polymerize<smiles></smiles><smiles>CB(O)Oc1ccccc1OB1Oc2ccccc2OB(Oc2ccccc2OB(C)O)Oc2ccccc2O1</smiles>

INFLUENCE OF THE ELECTROLYTE of salt anion radius to cation radius $[9,31,32]$. SALT COMPOSITION ON THE MELTING TEMPERATURE

One of the most important properties of an aprotic ionic liquid is its melting point. The analysis of the effect of steric and other factors on the melting temperature of tetraalkylamonium salts has identified the main traits influencing the melting temperature: cation $\left(\mathrm{R}_{\mathrm{C}}\right)$ and anion $\left(R_{A}\right)$ radius, cation symmetry and the ratio

1. The decrease in cation symmetry significantly influences the energy lattice and lowers even more the melting point (table 2). While the cation size grows at a stable charge, the melting temperature of tetraalkylamonium salt drops because of a decrease in cation polarization power and Coulomb power. The lattice energy decreases respectively. 
Table 2

Influence of cation symmetry on the melting temperature [33]

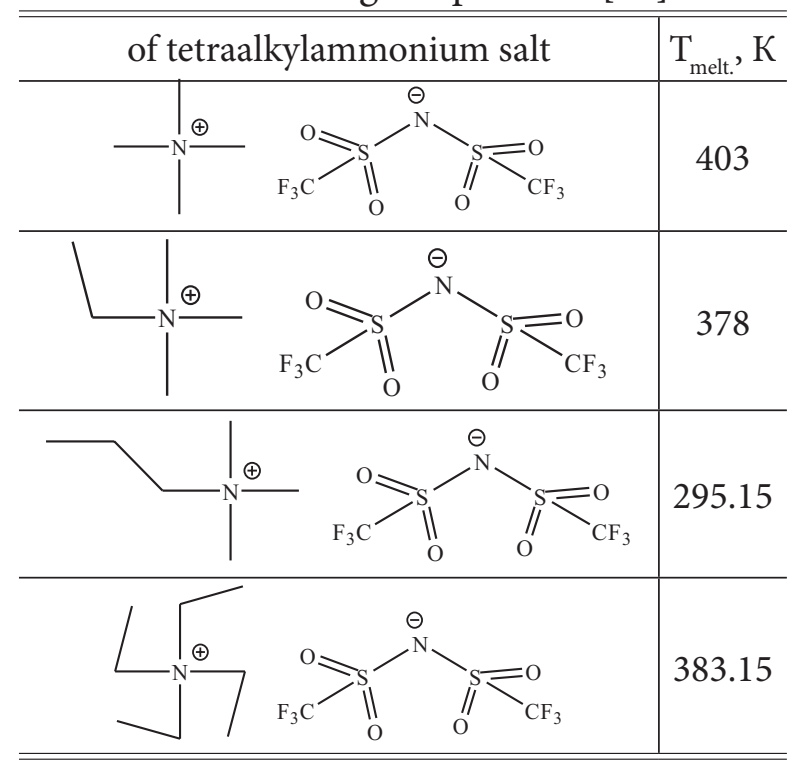

2. Decrease in the melting temperature of the tetraalkylammonium salt while the $\mathrm{R}_{\mathrm{A}} / \mathrm{R}_{\mathrm{K}}$ ratio increases (Figure 2 ).

3. The introduction of functional groups into thetetraalkylammoniumcation also helps to significantly decrease the melting point of tetraalkylammoniumsalts (Table 3). When both the cation and anion are of a big size, but $\mathrm{R}_{\mathrm{A}} / \mathrm{R}_{\mathrm{K}}=1$, the melting point will increase. Thus, the conditions needed for tetraalkylammonium salts to decrease their melting temperature can be noted as:

$$
\mathrm{R}_{\mathrm{A}} / \mathrm{R}_{\mathrm{C}}<1<\mathrm{R}_{\mathrm{A}} / \mathrm{R}_{\mathrm{C}}
$$

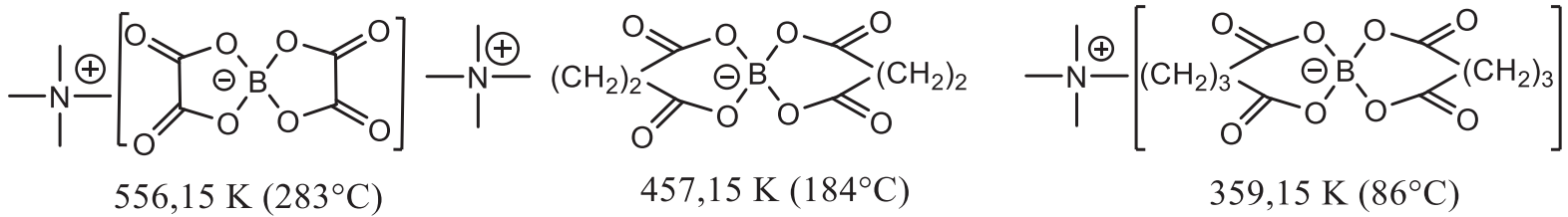

Figure 2 - The effect of tetraalkylammonium salt's melting temperature with increase of $R_{A} / R_{K}$ ratio.

\section{Table 3}

The change of the melting point with the introduction of functional groups into tetraalkylammonium cation [33]

\begin{tabular}{c|c|c|c|}
\hline \hline tetraalkylammonium salt & $\mathrm{T}_{\text {melt. }}, \mathrm{K}$ \\
\hline & & \\
\hline \hline
\end{tabular}

With increase in molecular weight, the radius ratio, radical branching or cation composition asymmetry lose their effect.

4. The reduction in anion symmetry has less impact on melting properties, its effect is significant on thetetraalkylammonium salt melting point.

Table 4 illustrates a melting point decrease with increasing size of the anion and with reduction in its symmetry. With increase in molecular weight, the radius ratio, radical branching or cation composition asymmetry lose their effect. For example, the melting temperature of tetraalkylammonium salt with the same anion 
decreases when the radical in thetetraalkylammonium cation changes from methyl to octyl, but it starts to increase with the formation of nonyl [11].

The reduction in anion symmetry has less impact on the melting point, but its effect is significant in the case of tetraalkylammonium salts (Table 4).

\section{Table 4}

Dependence of the melting temperature on the size of the anion [33]

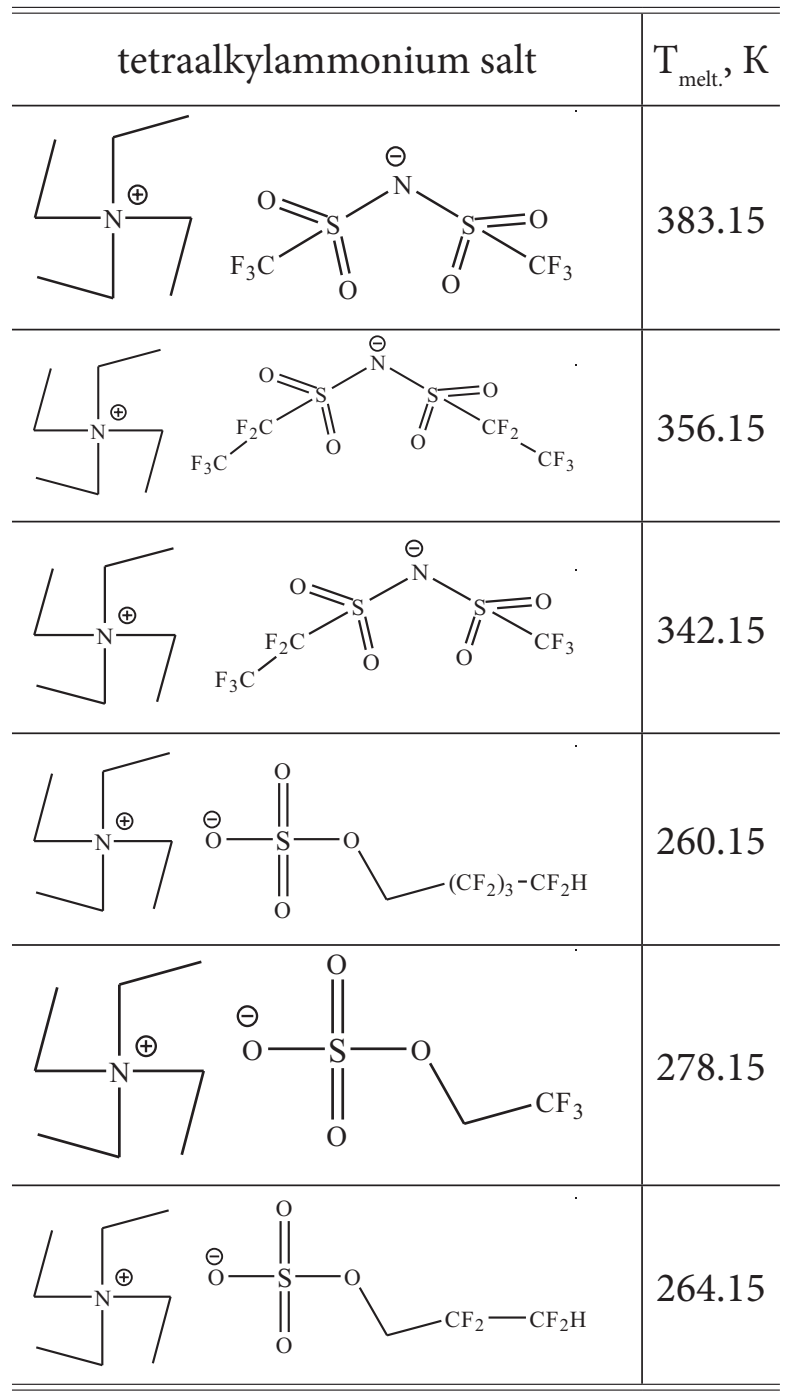

Thus, the study of the effect of the structure and symmetry of tetramethylammoniumbis (chelato) borate ions on the change of melting temperature is a task that facilitates the prediction of the electrochemical properties of electrolyte systems based on them.

COMPOSITION, STRUCTURE AND PROPERTIES OF POLYMERIC ELECTROLYTES

Solid electrolytes are divided according to the structure into crystalline, amorphous (glass) and polymeric ones. In crystalline and amorphous electrolytes, transport occurs due to thecation or anion sublattice. For them, there is a transition temperature in the superionic state (a dramatic change in the ionic conductivity of the cation/anion is recorded) when half the ionic lattice «melts» [1]. The polymeric electrolytes for lithium-ion batteries comprise most often a solution of typical lithium salts: $\mathrm{LiPF}_{6}$, $\mathrm{LiBF}_{4}, \mathrm{LiAsF}_{6}, \mathrm{LiN}\left(\mathrm{SO}_{2} \mathrm{CF}_{3}\right)_{2}$, and $\mathrm{LiSO}_{3} \mathrm{CF}_{3}$ in simple and polyester polymers, for example in polysiloxanes. The use of polymeric electrolytes expands their capabilities in batteries. Table 5 presents the main characteristics of liquid electrolytes (ionic liquids, solutions of salts in nonaqueous solvents) and polymeric electrolytes.

Crystalline and vitreous solid electrolytes have the same advantages for lithium energy sources as polymeric electrolytes, the only problem is posed by their fragility. So far, the conductivity of crystalline and vitreous solid materials is inferior to that of liquid electrolytes and is approximately $10^{-4}-10^{-5} \mathrm{Ohm}^{-1} \cdot \mathrm{cm}^{-1}$ at room temperature [45]. Most studies are devoted to lithium orthophosphate $\mathrm{Li}_{3} \mathrm{PO}_{4}$, lithium-substituted lanthanum titanate $\mathrm{La}_{2 / 3-\mathrm{x}} \mathrm{Li}_{3 \mathrm{x}} \mathrm{Me}_{1 / 3-2 \mathrm{x}} \mathrm{TiO}_{3}$ (where $\mathrm{Me}$ is a cation vacancy). A non-stoichiometric phase $\mathrm{Li}_{4} \mathrm{GeO}_{4}-\mathrm{Li}_{3} \mathrm{VO}_{4}$ in $\mathrm{Li}_{4} \mathrm{GeO}_{4}-$ $\mathrm{Li}_{3} \mathrm{PO}_{4}$ is obtained [45]. 
Table 5

Comparison of liquid and polymeric electrolytes properties when used in chemical energy sources.

\begin{tabular}{ccc}
\hline \hline Properties & Fluid electrolytes & Polymer electrolytes \\
\hline Electro conductivity & $\begin{array}{c}\text { High ion conductivity } \\
\left(\mathrm{Et}_{4} \mathrm{NBF}_{4} \text { in acetonitril 60 mSm/sm [42], }\right. \\
\text { typical electrolyte for lithium-ion battery } 10 \\
\text { mSm/sm [43]) }\end{array}$ & $\begin{array}{c}\text { Low ionic conductivity } \\
\left(10^{-4}-10^{-7} \mathrm{mS} / \mathrm{cm}\right)[44]\end{array}$ \\
\hline Energetic power & Low and medium power & medium and high power \\
\hline security & Flows due to liquid state or gas is formed & Does not flow \\
\hline Design / packaging & Solid protective case & $\begin{array}{c}\text { Slim, flexible, spatially } \\
\text { efficient, can be modeled for } \\
\text { blister packaging }\end{array}$ \\
\hline \hline
\end{tabular}

No type of electrolyte, liquid, solid or polymeric, has gained a decisive advantage over others. The liquid electrolytes based on concentrated solutions can dry up and form a salt film, which is inconvenient when sealing the elements. Moreover, they require special working conditions such as an extremely low humidity level. In addition, liquid electrolytes based on nonaqueous solutions have an expiration date. Liquid electrolytes are quite expensive and require a heavy case to assure a solid construction of hermetic package. The damage of the case leads to the failure of elements since contact with moisture makes the electrolyte incompatible with its functions. Polymer electrolyte compares favorably with liquid one. It does not require massive housing and is more mechanically stable, but at the same time, it has the same disadvantages as liquid electrolyte when exposed to the humid air. While the solid electrolytes compare favorably with the liquid and some polymeric electrolytes, they are not without their own drawbacks, e.g. low ionic conductivity. Taking this into account, further studies of solvents and temperature factors influence the formation of conductivity type, and the creation of conditions to increase the ionic conductivity in bis(chelato)borate based electrolyte systems is needed.

THE USE OF MONOVALENT CHELATOBORATE CATIONS IN BATTERIES AND SUPERCAPACITORS

Chelatoborates are highly heat-resistant compared to chelatophosphates $\mathrm{LiPF}_{6}$ and $\mathrm{LiBF}_{4}$.

An important feature of lithium bis(oxalato)borate and other lithium bis(chelato)borate mixtures is the ability to induce a decomposition reaction in the case of cathode overload; this slows down the voltage growth in the cell. Thanks to this property, the dangerous side reactions of the cathode material with electrolyte components can be prevented or reduced [46].

Borate electrolytes cause the formation of a very thin stable lithium ion conductive layer on the carbon anode of a lithium battery. It is stable at high temperatures and prevents therefore any hazardous reaction between the charged anode and electrode. This layer promotes the use of mangan spinel as a cathode material [46]. The improvement of the protective layer due to the borate salt has opened 
new possibilities of electrolyte formation. For example, this allowed us to avoid inconvenient -to- use ethylene carbonate and to use propylene carbonate instead. In addition, it allows to renounce the use of 1,3-dioxolane-2-on-compounds and to use gamma lactones such as gamma-butyrolactone [46] instead.

The review of the recently investigated chelatoborate salts [2-5, 47-56] permits us to make conclusions. Table 6 sums up the main characteristics of chelatoborates and chelatophosphate complexes of lithium salts, such as thermal stability, maximum solubility, electrical conductivity and electrochemical stability. The lithium chelatoborates formed by phenolic ligands have insufficient electrochemical stability and medium electrical conductivity $[3,4,5,52,54]$, and this problem remains even after phenolic ligands have been flourinated[3, 5, 48, 53]. The electrochemical stability of chelatophosphates is, despite their good conductivity, below $4 \mathrm{~V}$ $[49,50]$. Moreover, their synthesis is complicated and requires special conditions. The best results can be obtained on chelates with ligands containing a carboxyl group $[47,2,5,55,56]$. Lactate, malonate and croconatoborates have insufficient solubility in aprotic dipolar solvents and electrical conductivity despite their electrochemical stability of about $5 \mathrm{~V}$. Therefore, bis(oxalato)borate and lithium bis(salicylato) borate remain the most promising. The electrical conductivity and electrochemical stability in dipolar aprotic solvents in both of them is comparable to lithium hexaflurophosphate $[47,5]$.

Table 6

Physicochemical properties of chelato borates and lithium chelato phosphathes

\begin{tabular}{|c|c|c|c|c|c|}
\hline $\begin{array}{l}\text { Notation } \\
\text { keys }\end{array}$ & $\mathrm{t},{ }^{\circ} \mathrm{C}$ & $S, \mathrm{~mol} \mathrm{dm}^{-3}$ & $\sigma, \mathrm{mScm}^{-1}$ & $\begin{array}{c}\text { Electrochemical stability, } \\
\text { V }\end{array}$ & $\begin{array}{c}\text { Lit. } \\
\text { Source }\end{array}$ \\
\hline LBCB & 250 & $0,14(\mathrm{EC}+\mathrm{DME})$ & $2,40(\mathrm{EC}+\mathrm{DME})$ & $5,5(\mathrm{PC})$ & {$[47]$} \\
\hline LCSB & 328 & $0.16(\mathrm{EC}+\mathrm{DME})$ & $2.89(\mathrm{EC}+\mathrm{DME})$ & $5.0(\mathrm{PC})$ & [47] \\
\hline LiBSB & 350 & 1.41(EC+DME) & $5.08(\mathrm{EC}+\mathrm{DME})$ & $4.3(\mathrm{PC})$ & [47] \\
\hline LiLOB & & $0.93 \mathrm{~mol} / \mathrm{kg}(\mathrm{DME})$ & 6.52(DME) & $5.0(\mathrm{GBL})$ & [2] \\
\hline LiBLB & & $0.02 \mathrm{~mol} / \mathrm{kg}(\mathrm{GBL})$ & $0.01(\mathrm{GBL})$ & $>5.0(\mathrm{GBL})$ & [2] \\
\hline LBBB & 250 & $0.290(\mathrm{PC}+\mathrm{DME})$ & $5.99(\mathrm{PC}+\mathrm{DME})$ & $3.6(\mathrm{PC})$ & [3], [4] \\
\hline LBDOB & 256 & $0.302(\mathrm{PC}+\mathrm{DME})$ & 6.21(PC +DME) & $3.7(\mathrm{PC})$ & [3] \\
\hline LiBOB & 302 & $0.349(\mathrm{PC}+\mathrm{DME})$ & $7.79(\mathrm{PC}+\mathrm{DME})$ & $4.5(\mathrm{PC})$ & [5] \\
\hline F3LBBB & 256 & $0.283(\mathrm{PC}+\mathrm{DME})$ & 6.43(PC +DME) & $3.7(\mathrm{PC})$ & [5] [48] \\
\hline F3LBDOB & 262 & $0.284(\mathrm{PC}+\mathrm{DME})$ & 6.55(PC +DME) & $4.0(\mathrm{PC})$ & {$[3],[48]$} \\
\hline $\operatorname{LiP}\left(\mathrm{C}_{2} \mathrm{O}_{4}\right)_{3}$ & 150 & $20 \%(\mathrm{PC}+1,2-\mathrm{DME})$ & 9,7(PC +1,2-DME) & $4.0(\mathrm{PC})$ & [49] \\
\hline LiTBP & 150 & $0.5(\mathrm{EC}+\mathrm{DME})$ & $2.5(\mathrm{EC}+\mathrm{DME})$ & $3.7(\mathrm{PC})$ & [50]; [51] \\
\hline LBPB & - & - & - & $3.95(\mathrm{EC} / \mathrm{DMK} / \mathrm{PK}=4 / 4 / 1)$ & [52] \\
\hline LiFSB & - & $0.42 \mathrm{~m}(\mathrm{EC}+\mathrm{DME})$ & - & 4.6(EC/DMK) & [53] \\
\hline F4LBDOB & 270 & $0,4 \mathrm{~m} \mathrm{PC}$ & & $4.0-4.1\left({ }^{*} 12\right)(\mathrm{PC})$ & [5] \\
\hline LNBDB & 280 & & & $3.7(\mathrm{PC})$ & [5] \\
\hline LBBDB & 270 & & & 4.1(PC) & [54] \\
\hline LiMOB & 273 & $\begin{array}{l}0.5(\mathrm{GBL}) \\
0.08(\mathrm{PC})\end{array}$ & 5(GBL) & $\begin{array}{l}4.2(\mathrm{PC}) \\
5(\mathrm{GBL})\end{array}$ & $\begin{array}{l}{[55]} \\
{[56]}\end{array}$ \\
\hline
\end{tabular}


Bis(oxalato)borate has a severe disadvantage: it is able to interact with many different kinds of cathodes, but only when being paired with high- voltage anode materials or lithium anode, which is explained by its (borate) high reduction voltage in the first cycle.

However, the high price of lithium raw materials and limited lithium reserves in the Earth crust hold increasing demand for high current sources. Since lithium is a trace element, and its considerable reserves can be found only in South America, the ever-growing demand can cause speculation and influence the geopolitical situation in the world. A promising alternative to lithium-ion batteries is actively searched sodium-ion batteries. Sodium is an extremely common element and ten times cheaper [57-61]. Table7 compares sodium and lithium based systems [57]. It is also worth to mention that metallic lithium melts at $180.5^{\circ} \mathrm{C}$ and sodium metal at $97.7^{\circ} \mathrm{C}$. And this fact becomes extremely important when using them as anode materials. The low melting point of sodium limits the usage of sodium anode. The cathode and anode materials used in lithium-ion batteries are similar to those in sodium-ion batteries. However, some differences between them were identified. For example:

Table 7

Comparison of sodium and lithium based systems

\begin{tabular}{ccc}
\hline \hline category & lithium & Sodium \\
\hline Cation radius $(\AA)$ & 0.76 & 1.06 \\
\hline Atomic density & $6.9 \mathrm{~g} / \mathrm{mol}$ & $23 \mathrm{~g} / \mathrm{mol}$ \\
\hline Potential limit relative to $\mathrm{Li} / \mathrm{Li}^{+}$ & $-3.04 \mathrm{~V}$ & $-2.71 \mathrm{~V}$ \\
\hline the cost of the carbonate & $3850 \mathrm{Euro} / \mathrm{t}$ & $115 \mathrm{Euro} / \mathrm{t}$ \\
\hline Metal capacity $\mathrm{mA} / \mathrm{h}$ & 3829 & 1165 \\
\hline Coordination grid & Octahedron and tetrahedron & Octahedron and prism \\
\hline \hline
\end{tabular}

solid carbon and glassy carbon can be used as anodes, graphite properties in contrast were shown to be inadequate [57]. $\mathrm{FePO}_{4}$ is used as cathode material [58-60, 62-65], $\mathrm{NaFeO}_{2}$ as well as $\mathrm{NaCrO}_{2}$ [66-70] were resistant in contrast to the lithium analogs [71-73]. $\mathrm{NaPF}_{6}$ and $\mathrm{NaClO}_{4}$ solutions in carbonate or Glim solvents $[57,58,61]$ can also be used as electrolytes when with an aqueous electrolyte (sodium sulfate solution), $\mathrm{NaTi}_{2}\left(\mathrm{PO}_{4}\right)_{3}$ and $\mathrm{Na}_{2} \mathrm{FePO}_{4} \mathrm{~F}$ [74] are used as cathode and anode respectively.

Another important point is the presence of a protective solid ion-conductive film on the anode, which is formed as a result of destructive interaction with the electrolyte and prevents it from further destruction [61]. This film was observed on the sodium anode when working with a $\mathrm{NaPF}_{6}$ electrolyte in diglyme and tetralin. This electrolyte was proved to stay stable after being in operation with a sodium anode [61] for 300 cycles. The combination of $\mathrm{NaPF}_{6}$ with other solvents or other salts with diglyme and tetralin demonstrated significantly worse results. Like lithium systems, bis(chelato)borate sodium salt was tested in non-aqueous solvents [75]. Similar to lithium ion batteries, 
they create a protective film on the surface of cathode and anode materials.

However, this class of compounds is very little investigated in terms of solubility and conductivity in non-aqueous solvents. The only fact known is that bis(oxalato)borate and bis(salicylato)sodium borate are well soluble in DMFA and DMSO and very weakly soluble in acetonitrile and carbonate esters, in addition to the electrical conductivity data of these solutions [75], [76]. To determine the potential implication of bis(chelato)sodium borates, more detailed studies on the solubility in ADR and the electrochemical properties of these electrolytes are needed.

Recently, bis(chelato)borates of quaternary ammonium cations have been widely studied $[1113,77,78,31,32,79,80]$. They have a rather high thermal stability (e.g. $\mathrm{Et}_{4} \mathrm{NB}\left(\mathrm{C}_{2} \mathrm{O}_{4}\right)_{2}$ $\sim 220^{\circ} \mathrm{C}$ ) [78], but are inferior to $\mathrm{Et}_{4} \mathrm{NBF}_{4}$ in electrochemical stability. According to the analyzed literature data, the electrochemical stability of thebis(chelato)borates of quaternary ammonium cations does not correlate well with the cation nature: for example, bis(oxalate)borate, bis(2,2'-bisphenol)borates $\mathrm{Et}_{4} \mathrm{~N}^{+}, \mathrm{Me}_{4} \mathrm{~N}^{+}$ and tetraethylammoniumbis(1,2-ethoxy)borate, $2.5 \mathrm{~V}$ [77, 78]; 1-ethyl-3-methyl(oxalato) borate, $2.4 \mathrm{~V}$ [79, p. 91]. Moreover, in contrast to $\mathrm{Et}_{4} \mathrm{NBF}_{4}$ bis(oxalato)borate, tetraalkylammoniumcations are recommended, according to the patent [81], as a protective additive to electrolytes for lithium-ion batteries to protect the aluminum current collectors and other metallic parts of the battery structure from corrosion.

In addition, salicyloborates have been successfully tested as electrolytes for aluminum electrolytic capacitors [82], and oxalate-based ionic liquids proved to be radiation resistant and can be used in nuclear engineering [11].
We should mention electrolytes based on lithium trifluoroacetate. $\mathrm{CF}_{3} \mathrm{COOLi}$ salt is highly soluble only in water and is practically insoluble in aprotic dipolar solvents (ADS); it is traditionally used to prepare electrolytes in industrial and laboratory lithium power sources [28]. To eliminate these restrictions, this salt was added to polymer electrolytes [83]. Researchers [34, 35] have solved this problem in an original way - by using complexing agents for anions. The complexation of anions is a much more promising factor, as it increases both ion dissociation and lithium mobility. The boron-containing anionic complexing agents made it possible to obtain concentrated up to 1.2 $\mathrm{M}$ solutions of $\mathrm{CF}_{3} \mathrm{COOLi}, \mathrm{C}_{2} \mathrm{~F}_{5} \mathrm{CO} 2 \mathrm{Li}$ and even $\operatorname{LiF}$ (Fig. 3) [34, 35].

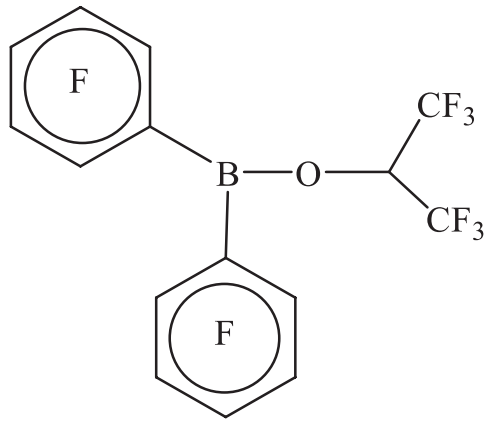

Figure 3 - Boron containing anionic complexing agent [34].

It should be pointed out that the complexing agent is introduced in an amount of $1 \mathrm{M}$ per $1 \mathrm{M}$ of salt. These works are still of considerable scientific interest, given the high chemical and thermal resistance of $\mathrm{CF}_{3} \mathrm{COOLi}\left(170^{\circ} \mathrm{C}\right)$ [35] and $\operatorname{LiF}$ (over $1000^{\circ} \mathrm{C}$ ). The electrochemical stability of multicomponent electrolytes with $\mathrm{CF}_{3} \mathrm{COOLi}$ and $\mathrm{LiF}$ is also quite high and is about $5 \mathrm{~V}$ in $\mathrm{EC} / \mathrm{DMC}$. But the process is significantly complicated and becomes unprofitable when the complexing agent is added. 


\section{Table 8}

Reduction on the first cycle of the lithium bis(oxalate)borate, bis(salicylo, oxalate)borate, bis(salicylo)borate and bis(malonato, salicylo)borate [84].
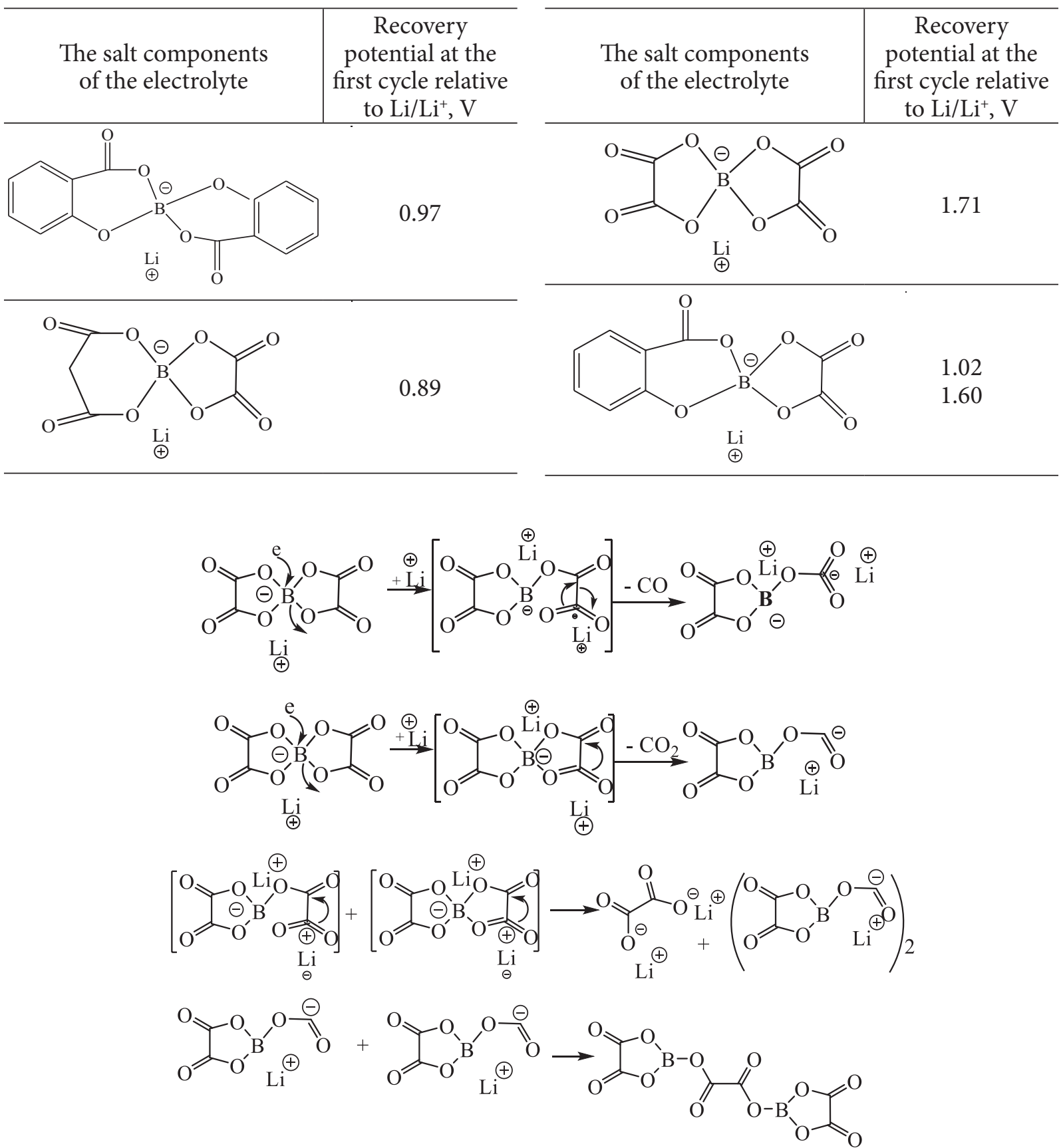

Figure 4 - Diagram of the reduction reaction and the formation of a solid electrolyte film on the electrode surface. 
Based on the nature of the ligand in the first cycle, various lithium chelate salts give rise to a reduction peak, which disappears in subsequent cycles (table 8). The peak correlates with salt decomposition, followed by the formation of a protective film with solid electrolyte properties [84], [85], [86]. One of the possible mechanisms of this process is illustrated by the example of well-known lithium bis(oxalato) borate (Fig. 4) [86].

The experiment with the salicylborate ani- on has shown that the coordination covalent bond in the aromatic nucleus has caused a shift of the reduction peak to higher potentials (table 8). Voltammetry is a sensitive method to detect impurities resulting from the hydrolysis of lithium chelate with water residues. The process has been studied in detail on lithium bis(oxalato)borate by gradually adding additional water to the electrolyte and identifying the hydrolysis products (Fig. 5) additionally, using IR spectroscopy and $\mathrm{H}^{1}$-NMR [86].

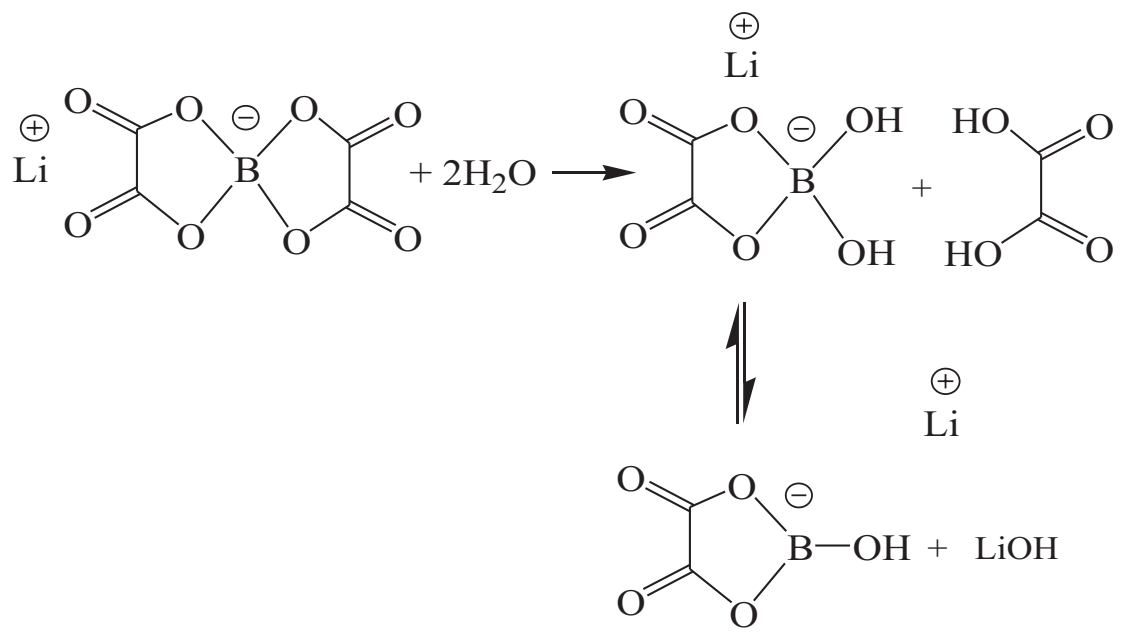

Figure 5 - Scheme of lithium bis(oxalato)borate hydrolysis [86].

\section{Conclusions}

The literature analysis has shown that chelate borates with boron-centered complex salicylborate anion are a modern and promising basis for chemical power sources, which include features of ionic fluids and due to changing the nature of cation and anion symmetry, could influence their electrochemical properties. Therefore, the use of other chelate borate ligands in the synthesis of salts with their further use in mixtures with different kinds of solvents is relevant and promising.
The work was done within research projects «Development of electrochemical systems with low overvoltage of cathode and anode processes and highly economical electrolyzers for obtaining high purity hydrogen», № State Registration 0110 001650 (2012-2014) and "Synthesis and physicochemical properties of inorganic electrocatalyst systems based on modified tungsten carbide metals Ib (Cu, Ag), IVb (Ti, $\mathrm{Zr}, \mathrm{Hf})$ and $\mathrm{Vb}(\mathrm{V}, \mathrm{Nb}, \mathrm{Ta})$ subgroups, for alternative electrochemical energy «, № State Registration 0110 U001650 (2015-2017). 
НОВІ НЕВОДНН ЕЛЕКТРОЛІТИ НА ОСНОВІ КОРДИНАЦЙНИХ СПОЛУК БОРУ

Діамант В. А.

Інститут загальної та неорганічної хімії імені В. І. Вернадського НАН Украӥни, просп. Акад. Палладіна, 32/34, Київ 03680, Україна email: carbon.h.4@gmail.com

В огляді наведено класифікацію електролітів для сучасних хімічних джерел струму, суперконденсаторів, натрій- та літій-іонних акумуляторів залежно від зміни фізико-хімічних властивостей солей та продуктів їхньої взаємодії з розчинником. Проведено порівняльний аналіз фізико-хімічних властивостей солей залежно від будови катіону та аніону та вплив цих властивостей на властивості кінцевих розчинів електролітів на прикладі різних класів йонних рідин та хелатоборатів лужних металів та амонію. Проаналізовано залежність фізико-хімічних властивостей електролітів (розчинність, електропровідність розчинів та діапазон потенціалів електрохімічної стійкості) від природи хелатного ліганду, електродонорних та електроакцепторних замісників у складі біс(хелато)боратного аніона. Проведено співставлення електропровідністі розчинів солей та діапазонів потенціалів електрохімічної стійкості відповідних електролітів, що містять інші аніони і які довгий час використовували в хімічних джерелах струму. Зазначено переваги та недоліки використання рідких електролітів порівняно $з$ твердими та по- лімерними електролітами з точки зору подібності їхніх структур. Показано, що природа хелатного ліганду, електродонорних та електроакцепторних замісників у складі біс(хелато)боратного аніона $є$ важливим фактором регулювання взаємодії з апротонними диполярними розчинниками. Змішані солі із двома різними хелатними лігандами, як правило, об'єднують найкращі характеристики відповідних монохелатних сполук, але методи їхнього отримання i очищення технологічно $€$ значно ускладненими порівняно з монохелатними сполуками. Зроблено аналіз механізму утворення захисної плівки на поверхні електродних матеріалів, залежності потенціалу ії утворення від хімічної природи і будови лігандів. Відзначено, що біс(хелато)боратні солі $є$ більш екологічно прийнятними порівняно із фторовмісними комплексними солями. Закцентовано увагу на фізико-хімічних властивостях розчинів найбільш перспективних хелатоборатних солей з метою застосування в літій- та натрій-іонних акумуляторах, суперконденсаторах та електролітичних конденсаторах, та показано, що біс(оксалато)борати та біс(саліцило)борати займають золотий перетин між усіма відомими біс(хелато)боратами за електропровідністю, розчинністю та діапазоном потенціалів електрохімічної стійкості.

Ключові слова: електроліти для літійіонних акумуляторів, біс(хелато)борати, іонні рідини, координаційні сполуки бору, суперконденсатори. 


\section{REFERENCES}

1. Damaskin B. B., Petriy O. A. Electrochemistry. Moscow: Kolos S. 2006. 672 p. [in Russian].

2. Wietelmann U., Lischka U., Schade K., Panitz J.-C. Boron Chelate Complexes. Patent: U. S. 7709663. 04.05.2010.

3. Xue Z. M., Zhao J. F., Ding J., Chen C. H. LBDOB, a new lithium salt with benzenediolato and oxalato complexes of boron for lithium battery electrolytes. Journal of Power Sources. 2010. 195(3): 853-856.

4. Barthel J., Wühr M., Buestrich R., Gores H. J. A New Class of Electrochemically and Thermally Stable Lithium Salts for Lithium Battery Electrolytes I. Synthesis and Properties of Lithium bis[1, 2-benzenediolato (2-)-O, O']borate. Journal of the Electrochemical Society. 1995. 142(8): 2527-2531.

5. Xue Z. M., Ji C. Q., Zhou W., Chen C. H. A new lithium salt with 3-fluoro-1, 2-benzenediolato and oxalato complexes of boron for lithium battery electrolytes. Journal of Power Sources. 2010. 195(11): 3689-3692.

6. Gray F. M. Solid polymer electrolytes: fundamentals and technological applications. New York: VCH. 1991. 256 p.

7. Reichardt K. Solvents and environmental effects in organic chemistry. Moscow: World. 1991. $763 \mathrm{p}$.

8. Kustov, L. M., T. V. Vasina, and V. A. Ksenofontov. Ion Liquids as Catalytic Media. Ross. Khim.Zh. 2004. 48(6): 13.

9. Ketabi S. Polymer-Ionic liquid Electrolytes for Electrochemical Capacitors: $\mathrm{PhD}$ thesis Toronto. 2015. 199 p.

10. Jain N., Kumar A., Chauhan S., Chauhan S.
Chemical and biochemical transformations in ionic liquids. Tetrahedron. 2005. 61(5): 1015-1060.

11. Lall-Ramnarine S. I., Castano A., Subramaniam G., Thomas M. F., Wishart J. F. Synthesis, characterization and radiolytic properties of bis(oxalato)borate containing ionic liquids. Radiation Physics and Chemistry. 2009. 78(12): 1120-1125.

12. Vijayaraghavan R., MacFarlane D. R. Effect of hydrophobic and hydrophilic organic salts on charge transfer polymerisation of styrene. European polymer journal. 2006. 42(8): 1830-1835.

13. Lewandowski A., Srwiderska-Mocek A. Ionic liquids as electrolytes for $\mathrm{Li}$-ion batteries-An overview of electrochemical studies. Journal of Power Sources. 2009. 194(2): 601-609.

14. Wang J., Li Y., Sun X. Challenges and opportunities of nanostructured materials for aprotic rechargeable lithium-air batteries. Nanoenergy. 2013. 2(4): 443-467.

15. Potapenko O. V., Kramarenko O. A., \& Prysjagnyj V. D. Solvate electrolytes for lithium current sources. Visn. Lviv. univ. Ser. Him.2002. 42: 146-148. [in Ukrainian].

16 Jain, P., Kumar, A. Comparable Ionicity of the Solutions of Aprotic and Protic Ionic Liquids by Anion Substitution. Journal of Solution Chemistry. 2017. 46(6): 13151327.

17. Wojnarowska, Z., Feng, H., Diaz, M., Ortiz, A., Ortiz, I., Knapik-Kowalczuk, J., ... \& Paluch, M. Revealing the charge transport mechanism in polymerized ionic liquids: Insight from high pressure conductivity studies. Chemistry of Materials. 2017. 29(19): 8082-8092. 
18. Gorobets M. I., Kirillov S. A., Gafurov M. M., Ataev M. B., \& Tretyakov D. O. Solvation and association of ions in system $\mathrm{LiClO}_{4}$ dimethylsulfoxide. Dopovidi NAN Ukrainy. 2014. 1:125-129. [in Ukrainian].

19. Kirillov S. A., Gorobets M. I., Gafurov M. M., Rabadanov K. S., \& Ataev M. B. Temperature dependence of associative equilibria DMSO by Raman spectra. Journal Phizitsheskoj Himii. 2014. 88(1):140142. [in Russian].

20. Gafurov, M. M., Kirillov, S. A., Rabadanov, K. S., Ataev, M. B., \& Tret'yakov, D. O. Spectroscopic study of solvation processes and ionic association in lithium salt solutions with ionic and aproticsolvents. Journal of Structural Chemistry. 2014. 55(1): 67-71.

21. Kirillov, S. A., Gorobets, M. I., Tretyakov, D. O., Ataev, M. B., \& Gafurov, M. M. Phase diagrams and conductivity of lithium salt systems in dimethyl sulfoxide, propylene carbonate and dimethyl carbonate. Journal of Molecular Liquids. 2015. 205: 78-84.

22. Gafurov, M. M., Kirillov, S. A., Gorobets, M. I., Rabadanov, K. S., Ataev, M. B., Tretyakov, D. O., \& Aydemirov, K. M. Phase equilibria and ionic solvation in the lithium tetrafluoroborate - dimethylsulfoxide system. Journal of Applied Spectroscopy. 2015. 81(6): 912-918.

23. $\mathrm{Xu} \mathrm{K}$. Nonaqueous Liquid Electrolytes for Lithium-Based Rechargeable Batteries. Chemical Reviews. 2004. 104(10): 43034417.

34. Nikolsky B.P. Handbook of the chemist. Leningrad: Chemistry, 1971. 1169 p. (2). [rus]

25. Dudley J., Wilkinson D., Thomas G., Le-
Vae R. Conductivity of electrolites for rehargeble lithium batteris. Journal of Poweer Sources. 1991. 35(1): 59-82.

26. Yang H., Zhuang G., Ross P. Thermal Stability of LiPF6 Salt and Li-ion Battery Electrolytes Containing LiPF . Journal of Power Sources. 2006. 161(1): 573-79.

27. Webber A. Conductivity and Viscosity of Solutions of LiCF3SO3, $\mathrm{Li}\left(\mathrm{CF}_{3} \mathrm{SO}_{2}\right)_{2} \mathrm{~N}$, and Their Mixtures. Journal of The Electrochemical Society. 1991. 138(9): 25862590 .

28. Schalkwijk W. Advances in Lithium-ion Batheries. New York: Kluwer Academic. 2002. $507 \mathrm{p}$.

29. Dominey L., Koch V., Blakley T. Thermally stable lithium salts for polymer electrolytes. Electrochimical Acta. 1992. 37(9): 1551-1554.

30. Sirenko I. Lithium fluorosulfonate as a component of electrolytes of lithium current sources: $\mathrm{PhD}$ thesis: 02.00.05. Kyiv. 2000. 118 p. [in Ukrainian].

31. Kirchner B. Ionic Liquids Volume Editor. Heidelberg: Springer. 2009. 354 p.

32. Dean P. M., Pringle J. M., MacFarlane D. R. Structural analysis of low melting organic salts: perspectives on ionic liquids. Physical Chemistry Chemical Physics. 2010. 32(12): 9144-9153.

33. House L., Hill J. Ionic Liquids Physicochemical Properties. Amsterdam: Elsevier. 2009.478 p.

34. Lee H. S., Yang X. Q., McBreen J., Okamoto Y., Choi L. S. A new family of anion receptors and their effect on ion pair dissociation and conductivity of lithium salts in non-aqueous solutions. Electrochimical Acta. 1995. 40 (13-14): 2353-2356.

35. McBreen, J., Lee H. S., Yang X. Q. Syn- 
thesis of a new family of fluorinated boronate compounds as anion receptors and studies of their use as additives in lithium battery electrolytes. Proceedings on China International Battery Fair. 2001. 9798(7): 566-569.

36. Pershina E.D., Karpushin N.A., Kazdobin K.A. Aluminosilicate conductivity at the presence of water. Surf. Engin. Appl. Electrochem. 2010.46 (10): 339-347.

37. Diamant V.A., Malovanyy S.M., Pershina K.D., Kazdobin K.A. Electrochemical properties of Sodium bis[salicylato(2-)]-borate - $\gamma$-butyrolactone Electrolytes in Sodium Battery. Materialstoday Proceedings. 2019. 6(2): 86-94.

38. Pershina, K.D., Kokhanenko, V.V., Masliuk, L.N. et al. Energy transformation in water and oxygen-containing electrolytes. Surf. Engin. Appl. Electrochem. 2012. 48(3): 90-96.

39. Diamant, V.A., Pershina, E.D., Trachevsky, V.V. et al. Physicochemical properties of tetramethylammoniumbis(salicylo) borate. Russ. J. Appl. Chem. 2015. 88(9): 901-907.

40. Diamant, V., Trachevskii, V., Pershina, K., Ogenko, V., Donchu, C., Huawen, H., Min, C., Xiaowen, W., \& Menglei, C. (2019). Specialties of the structure and conductivity of the non-aqueous electrolytes based on alkali metal bis(salicyl)borates and bis(oxalate)borates. Ukrainian Chemistry Journal. 2019. 85(3): 49-55.

41. Schwartz, E.M. Complex boron compounds with polyoxy compounds. Riga: Publishing House of the Academy of Sciences of the Latvian SSR. 1968. 224 p.

42. Dobosh D. Electrochemical Constants: A Handbook for Electrochemists. Moscow:
Mir. 1980. 365 p.

43. Gali'nski M., Lewandowski A., Stepniak I. Ionic liquids as electrolytes. Electrochimica acta. 2006. 51: 5567-5580.

44. Syromyatnikov V. G., Pascal L. P., Mashkin O. A. Polymeric electrolytes for lithium chemical current sources. Chemistry Advances. 1995. 64(3): 265-274.

45. Ivanov-Shits A. K., Demyanets L. N. Materials of the Ionic of a Solid. Priroda. 2003. (12): 35-43.

46. Gores H. J., Multerer M., Schweiger H.-G. Elektrolyt zur Verwendung in elektrochemishen Zellen. Patent DE 102006055 770.06.28. 2007.

47. Xue Z. M., Wu K. N., Liu B., Chen C. H. New lithium salts with croconato-complexes of boron for lithium battery electrolytes. Journal of Power Sources. 2007. 171(2): 944-947.

48. Barthel, J., Buestrich R., CarlE., Gores H. J. A New Class of Electrochemically and Thermally Stable Lithium Salts for Lithium Battery Electrolytes. Journal of the Electrochemical Society. 1996. 143(11): 3565-3571.

49. Wietelmann U., Schade K., Lischka U. Tris (oxalato) phosphates, method for their preparation and their use. Patent 6,693,212 U.S. 17.02.2004.

50. Handa M., Suzuki M., Suzuki J., Kanematsu H., Sasaki Y. A new lithium salt with a chelate complex of phosphorus for lithium battery electrolytes. Electrochemical and solid-state letters. 1999. 2(2): 60-62.

51. Nanbu N., Tsuchiya K., Sasaki Y. Electrolytic properties of lithium chelatophosphates and application to lithium batteries. Journal of power sources. 2005. 142(1-2): 333-338. 
52. Barthel J., Schmid A., Gores H. J. A New Class of Electrochemically and Thermally Stable Lithium Salts for Lithium Battery Electrolytes. V. Synthesis and Properties of Lithium Bis [2, 3-pyridinediolato (2-)$\left.\mathrm{O}, \mathrm{O}^{\prime}\right]$ borate. Journal of the Electrochemical Society. 2000. 147(1): 21-24.

53. Barthel J., Schmidt M., Gores H. J. Lithium Bis [5-fluoro-2-olato-1-benzenesulfonato (2-)-O, $\left.\mathrm{O}^{\prime}\right]$ borate (1-), a New Anodically and Cathodically Stable Salt for Electrolytes of Lithium-Ion Cells. Journal of The Electrochemical Society. 1998. 145(2): L17-L20.

54. Barthel J., Buestrich R., Gores H. J., Schmidt M., Wühr M. A new class of electrochemically and thermally stable lithium salts for lithium battery electrolytes IV. Investigations of the electrochemical oxidation of lithium organoborates.Journal of The Electrochemical Society. 1997. 144(11): 3866-3870.

55. Xu W., Shusterman A. J., Marzke R., Angell C. A. Lithium (MalonatoOxalato) Borate: A New Asymmetric Chelatoborate Salt. In The 204th Meeting of the Electrochemical Society, Orlando, Florida USA. 2003. 10(10): 110-116.

56. Panitz J.-C., Pötschke D. R., Wietelmann U. Leitsalzefürgalvanischezellen, Derenherstellung und Verwendung. Patent 086274 DE. 15.09.2005.

57. Engelke, Simon. Current and future sodium-ion battery research. International Journal of Energy Storage. Draft 2013: $1-7$.

58. Cutler R. W. Electrolyte Optimization Study for $\mathrm{TiO}_{2}$ Nanotube Electrode in Sodium Ion Batteries. PhD thesis: Boise. 2015.
59. Fang Y., Xiao L., Qian J., Ai X., Yang H., Cao Y. Mesoporous amorphous $\mathrm{FePO}_{4} \mathrm{n}$ anospheres as high-performance cathode material for sodium-ion batteries. Nano letters. 2014. 14(6): 3539-3543.

60. Liu Y., Xu Y., Han X., Pellegrinelli C., Zhu Y., Zhu H., Hu L. Porous amorphous $\mathrm{FePO}_{4}$ nanoparticles connected by single-wall carbon nanotubes for sodium ion battery cathodes. Nano letters. 2012. 12(11): 5664-5668.

61. Seh Z. W., Sun J., Sun Y., Cui Y. A highly reversible room-temperature sodium metal anode. ACS central science. 2015. 1(8): 449-455.

62. Moreau P., Guyomard D., Gaubicher J., Boucher F. Structure and stability of sodium intercalated phases in olivine $\mathrm{FePO}_{4}$. Chemistry of Materials. 2010. 22(14): 4126-4128.

63. Zhu Y., Xu Y., Liu Y., Luo C., Wang, C. Comparison of electrochemical performances of olivine $\mathrm{NaFePO}_{4}$ in sodium-ion batteries and olivine $\mathrm{LiFePO}_{4}$ in lithium-ion batteries. Nanoscale. 2013. 5(2): 780-787.

64. Lee K. T., Ramesh T. N., Nan F., Botton G., Nazar L. F. Topochemical synthesis of sodium metal phosphate olivines for sodium-ion batteries. Chemistry of Materials. 2011. 23(16), 3593-3600.

65. Pan H., Hu Y. S., Chen L. Room-temperature stationary sodium-ion batteries for large-scale electric energy storage. Energy \& Environmental Science. 2013. 6(8), 2338-2360.

66. Yu C. Y., Park J. S., Jung H. G., Chung K. Y., Aurbach D., Sun Y. K., Myung S. T. $\mathrm{NaCrO}_{2}$ cathode for high-rate sodium-ion batteries. Energy \& Environmental Sci- 
ence. 2015. 8(7): 2019-2026.

67. Myung S. T., sang Park J., Jung H. G., Chung K. Y., Aurbach D., Yu C. Y., Sun Y. K. NaCrO 2 Cathode for High-Rate Sodium-Ionbatteries. In Meeting Abstracts The Electrochemical Society. 2016. 9: 664664.

68. Ding J. J., Zhou Y. N., Sun Q., Fu Z. W. Cycle performance improvement of $\mathrm{Na}$ $\mathrm{CrO}_{2}$ cathode by carbon coating for sodium ion batteries. Electrochemistry Communications. 2012. 22: 85-88.

69. Komaba S., Takei C., Nakayama T., Ogata A., Yabuuchi, N. Electrochemical intercalation activity of layered $\mathrm{NaCrO}_{2}$ vs. $\mathrm{LiCrO}_{2}$. Electrochemistry Communications. 2010. 12(3): 355-358.

70. Xia X., Dahn J. R. $\mathrm{NaCrO}_{2}$ is a fundamentally safe positive electrode material for sodium-ion batteries with liquid electrolytes. Electrochemical and Solid-State Letters. 2011. 15(1): A1-A4.

71. Zhao J., Zhao L., Dimov N., Okada S., Nishida T. Electrochemical and thermal properties of $\alpha-\mathrm{NaFeO} 2$ cathode for $\mathrm{Na}$ ion batteries. Journal of The Electrochemical Society. 2013. 160(5): A3077-A3081.

72. Yabuuchi N., Yoshida H., Komaba S. Crystal structures and electrode performance of alpha-NaFeO2 for rechargeable sodium batteries. Electrochemistry. 2012. 80(10): 716-719.

73. Yabuuchi N., Kajiyama M., Iwatate J., Nishikawa H., Hitomi S., Okuyama R., Komaba S. P2-type $\mathrm{Na}_{\mathrm{x}}\left[\mathrm{Fe}_{1 / 2} \mathrm{Mn}_{1 / 2}\right] \mathrm{O}_{2}$ made from earth-abundant elements for rechargeable $\mathrm{Na}$ batteries. Nature materials. 2012. 11(6): 512.

74. Shirpour M., Zhan X., Doeff M. In Sodium-Ion Batteries: Beyond Lithium-Ion. In
2015 TechConnect World Innovation Conference. 2015.

75. Ge C., Wang L., Xue L., Wu Z. S., Li H., Gong Z., Zhang X. D. Synthesis of novel organic-ligand-doped sodium bis(oxalate) borate complexes with tailored thermal stability and enhanced ion conductivity for sodium ion batteries. Journal of Power Sources. 2014. 248: 77-82.

76. Zavalij P. Y., Shoufeng Y., Whittingham M. S. Structures of potassium, sodium and lithium bis(oxalato)borate salts from powder diffraction data. ActaCrystallographica Section B: Structural Science. 2003. 59(6): 753-759.

77. Waldvogel S., Malkowsky I., Griesbach U., Pötter H. Novel fluorine-free electrolyte system for supercapacitors. Electrochemistry Communications. 2009. 11(6): 12371241.

78. Nanbu N., Ebina T., Uno H., Ishizawa S. Physical and electrochemical properties of quaternary ammonium bis(oxalato)borates and their application to electric double-layer capacitors. Electrochimica Acta. 2006. 52(4): 1763-1770.

79. Bruglachner, H. Neue elektrolyte für doppelschichtkondensatoren. $\mathrm{PhD}$ thesis $\mathrm{Re}-$ gensburg. 2004. 224 p.

80. Smirnova N. N., Tsvetkova L. Y., Bykova T. A., Ruchenin V. A., Marcus Y. Thermodynamic properties of tetrabutylammonium iodide and tetrabutylammoniumtetraphenylborate. Thermochimica Acta. 2009. 483(1-2): 15-20.

81. Wietelmann U., et al. Method for the production of hydrogen-bis(chelato)borates and alkali metal-bis(chelato)borates. Patent U.S. No. 7, 208,131. 24.04.2007.

82. Ue M., Shima K., Mori S. Electrochemical 
properties of quaternary ammonium borodiglycolates and borodioxalates. Electrochimicaacta. 1994. 39(18): 2751-2756.

83. Delgado M. I., Jurado N. M., Vargas R. A. Phase diagram of polymer electrolyte:(x) (PEO)-(1-x) CF3COOLi. Revista Facultad de Ingeniería Universidad de Antioquia. 2012. (62): 77-82.

84. Kaymaksiz S., Wilhelm F., Wachtler M., Wohlfahrt-Mehrens M., Hartnig C., Tschernych I., Wietelmann U. Electrochemical stability of lithium salicylato-borates as electrolyte additives in Li-ion batteries.
Journal of Power Sources. 2013. 239: 659-669.

85. Xie B., Li L., Li H., Chen L. A preliminary study on a new LiBOB/acetamide solid phase transition electrolyte. Solid State Ionics. 2009.180(9-10): 688-692.

86. Yang L., Furczon M. M., XiaoA., LuchtB.L., Zhang Z., Abraham D. P. Effect of impurities and moisture on lithium bis(oxalato)borate $(\mathrm{LiBOB})$ electrolyte performance in lithiumion cells. Journal of Power Sources. 2010. 195(6): 1698-1705.

Стаття надійшла 29.10.2020. 